\title{
Analysis of Support Design in Weak Rock Drift Using a Systematic Approach
}

\author{
Xingdong Zhao $\mathbb{D},{ }^{1}$ Shujing Zhang, ${ }^{1}$ Huaibin Li $\mathbb{D},{ }^{1}$ Guoju Chen, ${ }^{2}$ and Pengqiang Zhang ${ }^{2}$ \\ ${ }^{1}$ Geomechanics Research Center, Northeastern University, Shenyang, Liaoning 110819, China \\ ${ }^{2}$ State Key Laboratory of Nickel and Cobalt Resources Comprehensive Utilization, Jinchang, Gansu 737100, China \\ Correspondence should be addressed to Xingdong Zhao; zhaoxingdong@mail.neu.edu.cn
}

Received 2 July 2020; Revised 14 August 2020; Accepted 30 August 2020; Published 21 September 2020

Academic Editor: Fengqiang Gong

Copyright (c) 2020 Xingdong Zhao et al. This is an open access article distributed under the Creative Commons Attribution License, which permits unrestricted use, distribution, and reproduction in any medium, provided the original work is properly cited.

\begin{abstract}
The aim of this study is to develop a systematic approach for support design of weak rock drift based on empirical, analytical, and numerical method, which is employed to estimate weak rock support demand and design support system. Detailed engineering geological investigations and rock mechanics test have been carried out in weak rock drift. The Q-system and GSI-system were used to determine the primary support design and rock mass properties, respectively. The numerical model of RS2 finite element program has been calibrated by analyzing the relation of falling height observed in the field to the frictional angles obtained from empirical method, rock mechanics test, and calculated rock mass parameters, respectively. In an attempt to check the validity of sophisticated support, support suggested by Q-system, and the combination support system proposed by analytical approach, the RS2 program was employed to analyze the depth of plastic zone and total displacement surrounding the weak rock drift. Numerical results show that the depths of plastic zone and total deformation surrounding the weak rock drift supported by the combination support system significantly descended $87 \%$ and $90 \%$ of those of sophisticated support. In particular, the rock bolt and cable bolt provide enough frictional and interlocked forces to resist weak rock falling which change the weak rock mechanicals properties and the surface holding function reinforced by the shotcrete, wire mesh, and steel strap. The factor of safety (FOS) of 8.28 of the combination support system is much more than the FOS of 1.5 for permanent drift. The combination support system with rock bolts, cable bolt, shotcrete, wire mesh, and steel straps has been applied to stabilize the weak rock drift and found to be successful to prevent further deformations surrounding the drift.
\end{abstract}

\section{Introduction}

Weak rock does not have an appropriate and unified definition in engineering geology [1]; it is a transitional rock type between no-cohesive soil and hard rock, and its unconfined compressive strength is less than $50 \mathrm{MPa}[2,3]$. Ground support in weak rock presents some special geotechnical challenges, such as rock fall and support deformation in development heading. The load distribution and interaction between several reinforcement and surface support elements are associated with the support design of weak rock. Since misjudgments of support design can lead to underdesign and costly failure or overdesign and high drift costs for unneeded ground support [4], weak rock drift requires a very different approach to design ground support, which needs to examine some basic concepts of how a rock mass surrounding a drift deforms and how the support system acts to control this deformation.

The deformation behavior of weak rock is predominantly controlled by rock mass properties such as low strength, high deformability, discontinuities [5], weathering or alteration conditions, and mechanical disruption such as blasting and excavation stand-up time [6]. Within a weak rock, the depth of failure has been noted by field observation as 0.5 times or one time the span and sometimes even greater [7]. Empirical methods, such as RQD, RMR, and Q-system, do not specifically address some of the unique characteristics of weak rock related to potential overstressing or deterioration [5]. 
The database of RMR is based largely on stoping methods [6], and no special parameter is used for drift support [8]. The Q-system has several limitations, working best between $Q=0.1$ and $Q=40$ for tunnels with spans between $2.5 \mathrm{~m}$ and 30m [9]. However, the Q-system further breaks down "very poor" rock quality category to "extremely and exceptionally poor" and introduction of the SRF factor which provides more focus for classification of rock mass having poorer mechanical characteristics compared to RQD and RMR [10]. Applying $Q$ to a mine is like importing a knowledge database to a mine [11] for assisting ground support selection. However, in the "very poor rock class ( $Q$ less than 1$)$ " the Q-system may give erroneous support design. The GSI developed by Hoek [12] can be used for weak rock characterization.

It is probably because the failure nature of weak rock is complex and difficult to analyze with no straightforward mathematical or numerical analysis models or recommended factor of safety defining an acceptable limit for the failure [13-15]. For weakness zones, the rock support should be evaluated separately for each and every case [14]. The extents of failure zones and probable displacement are determined by numerical methods, which provide the basic information and demand on ground support as well as the capacity of a ground support system. Very limited research and literature exist on the practical application of a support system under weak rock conditions. There are some issues in the process of designing support for weak rock drift, where weak rock requires the use of structural supports, either to reestablish equilibrium or to limit rock displacements around the tunnel [15]. Empirical and numerical approaches are useful tools to overcome these difficulties.

In this paper, a systematic approach for the design of weak rock support system was proposed with regard to engineering geological investigation, loading conditions, and rock mechanics test. A combination support system was proposed by analytical approach and modified according to rock mass properties, falling height, and factor of safety. The numerical modeling to validate the combination support design is helpful to similar engineering geological conditions of weak rock support.

\section{Site Descriptions}

Xinli mine zone of Sanshandao Gold Mine is the first subsea gold mine along the coastline of China [16], located about $29 \mathrm{~km}$ north of Laizhou city and $45 \mathrm{~km}$ west of Zhaoyuan city, China, and extends from about $-40 \mathrm{~m}$ level to $-600 \mathrm{~m}$ level below undersea level. The orebody has a strike of SW of $60-70^{\circ}$ and a dip angle of $40^{\circ}$ to $50^{\circ}$ towards southeast [17]. There is about $10 \mathrm{~m}$ depth of sea water on the top of the gold deposit in Xinli Gold Mine [18]. The gold deposit buried in bedrock is irregularly seamed. The lithological units in the study area derived from altered zone of orebody deposit are medium-grained biotite adamellite $(\eta \mathrm{Y})$, beresitization granitic cataclasite (SYJH), fault, phyllic granitic cataclasite (SYJ) (footwall), beresitization granitic cataclasite $(\mathrm{SJH}$, orebody) and major fracture plane, beresitization cataclasite $(\mathrm{YJ})$, and medium-fine-grained metagabbro ( $v)$
(Hangingwall) as shown in Figure 1. The multiple faults distribution of the geological cross section in SW orebody of Xinli mine is presented in Figure 2.

Drift driven by drill and blast method and rock falls in unsupported areas and deformation in the supported area (U-shaped steel sets support, width $100 \mathrm{~mm}$, spacing $1 \mathrm{~m}$ ) were the most commonly observed shapes of instabilities in drift (Figure 3); the falling height is about $1.5-4 \mathrm{~m}$ in unsupported heading (Figure 4), even completely falling from one to author level ( $-253 \mathrm{~m}$ level to $-240 \mathrm{~m}$ level), which caused great difficulties in further development. Therefore, support design in weak rock needs to be redesigned according to engineering geological conditions of weak rock.

\section{Methodology}

Ground control for weak rock is geotechnical challenges associated with sudden fall height and large deformation. A systematic approach for weak rock support is illustrated in Figure 5 and is as follows: (1) collecting basic information including the engineering geology investigation, rock mechanics tests, in situ condition, shapes and height of falling, and so forth; (2) rock mass classification based on Q-system and GSI-system and determination of rock mass characterization and preliminary support design; (3) calibration the RS2 numerical model based on the frictional angles and falling height of field observation; (4) identifying potential geotechnical hazards and the ground responses of different support design; (5) evaluation of ground demand; (6) optimizations of support system based on analytical approach and numerical simulation; and (7) calculation factor of safety (FOS).

\section{Weak Rock Mass Characterization}

4.1. Field Investigation and Data Collection. A detailed engineering geological investigation was carried out by scanline surveys between \#115 and \#159 exploration sections in $-320 \mathrm{~m}$ level drift in the footwall at Xinli mine. A total of 124 rock discontinuities were determined in the field in accordance with the ISRM suggested methods [19]. Discontinuity orientations were processed by utilizing a computer software, called Dips v5.1 [20], and four joint sets drawn and presented in Figure 6. Those joint sets exhibit a spacing varying between $0.10 \mathrm{~m}$ and $0.33 \mathrm{~m}$.

In the absence of RQD measurements, line mapping data can be used to estimate RQD through methods proposed by Bieniawski, Palmström, and Hutchinson et al. [21-23]. The estimated RQD value represents the maximum RQD value which is 35 .

4.2. Laboratory Tests. Laboratory experiments [19] were carried out to determine the physical and mechanical properties of phyllic granitic cataclasite, including unit weight, uniaxial compressive strength, and tensile strength. In addition, deformability or stress-strain tests were undertaken to determine Young's modulus $(E)$ and Poisson's ratio $(v)$. The test results are given in Table 1 . The rock had UCS values of $39.2 \mathrm{MPa}$, dominantly $>25 \mathrm{MPa}$. Further, the 


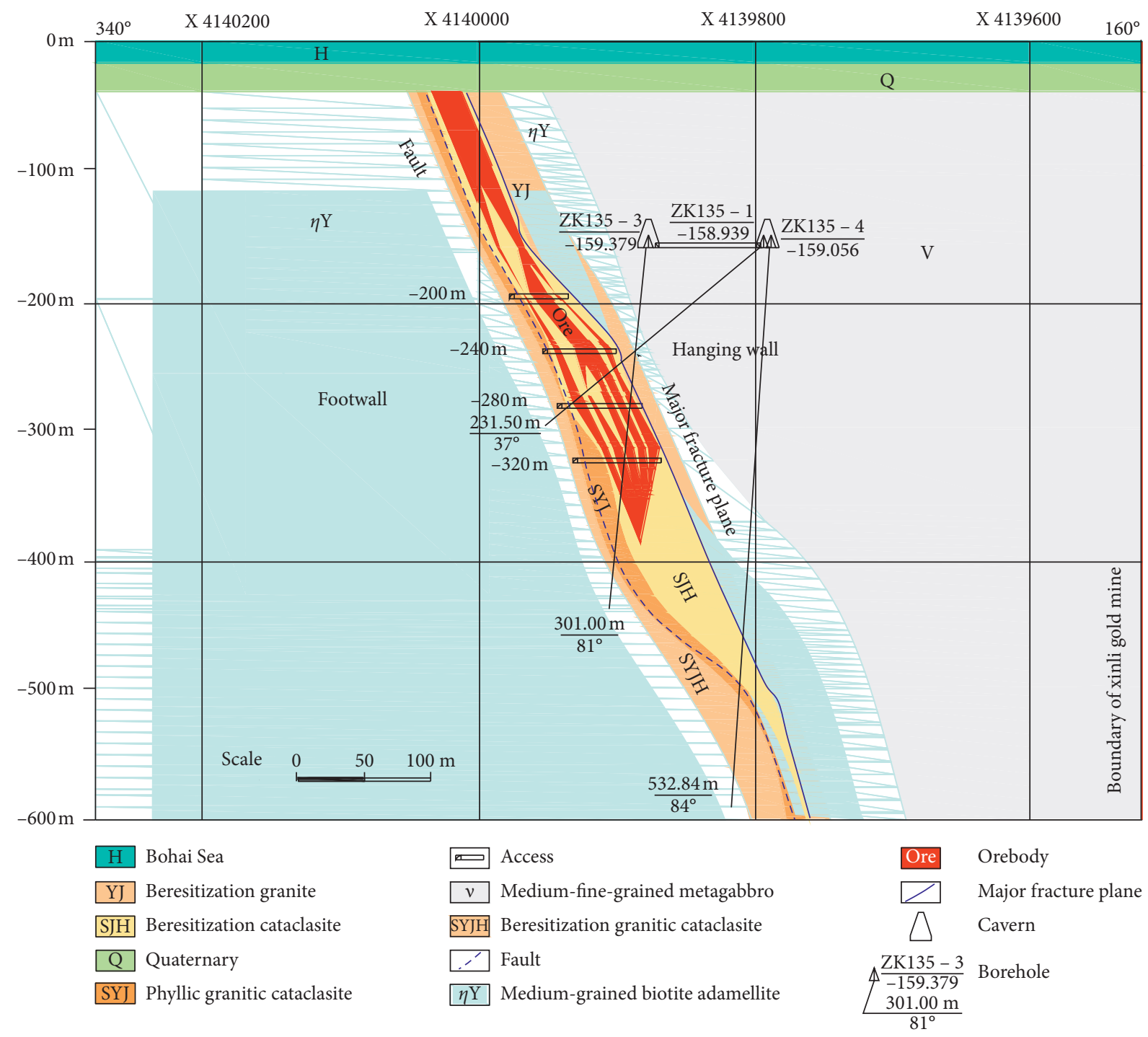

Figure 1: Profile map showing the geological structure of orebody at \#135 exploration section.

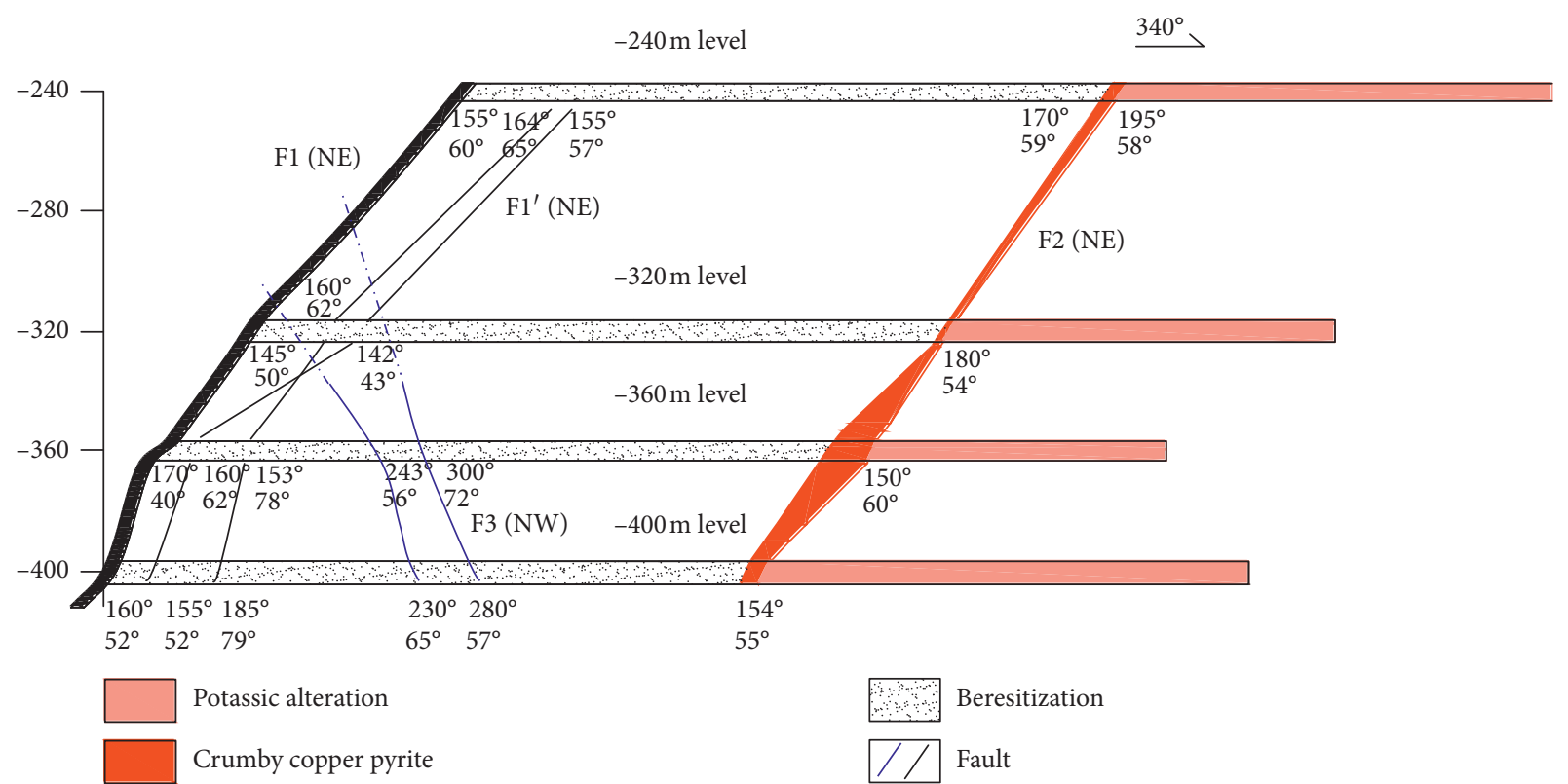

FIgURE 2: The multiple faults distribution of the geological cross section in SW orebody of Xinli mine. 

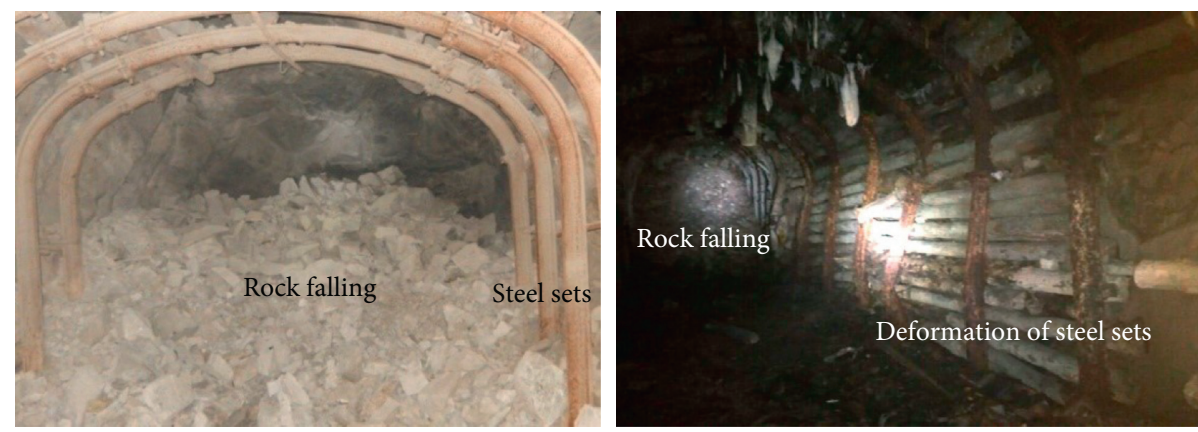

FIGURE 3: The rock falling and deformation of steel sets in the weak rock drift.
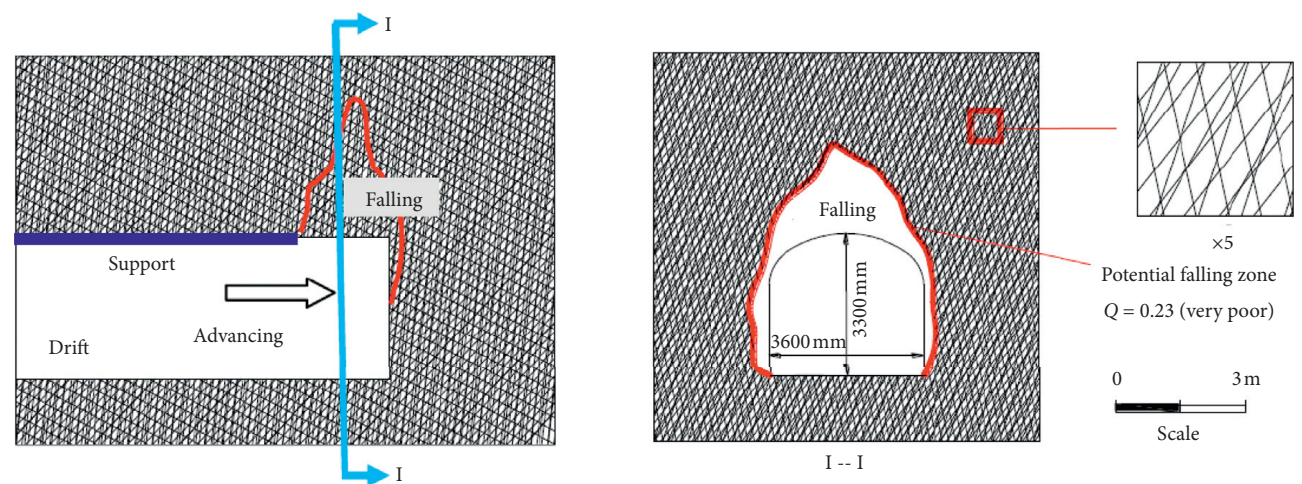

FIGURE 4: The shape and height of falling in the unsupported drift according to field observation.

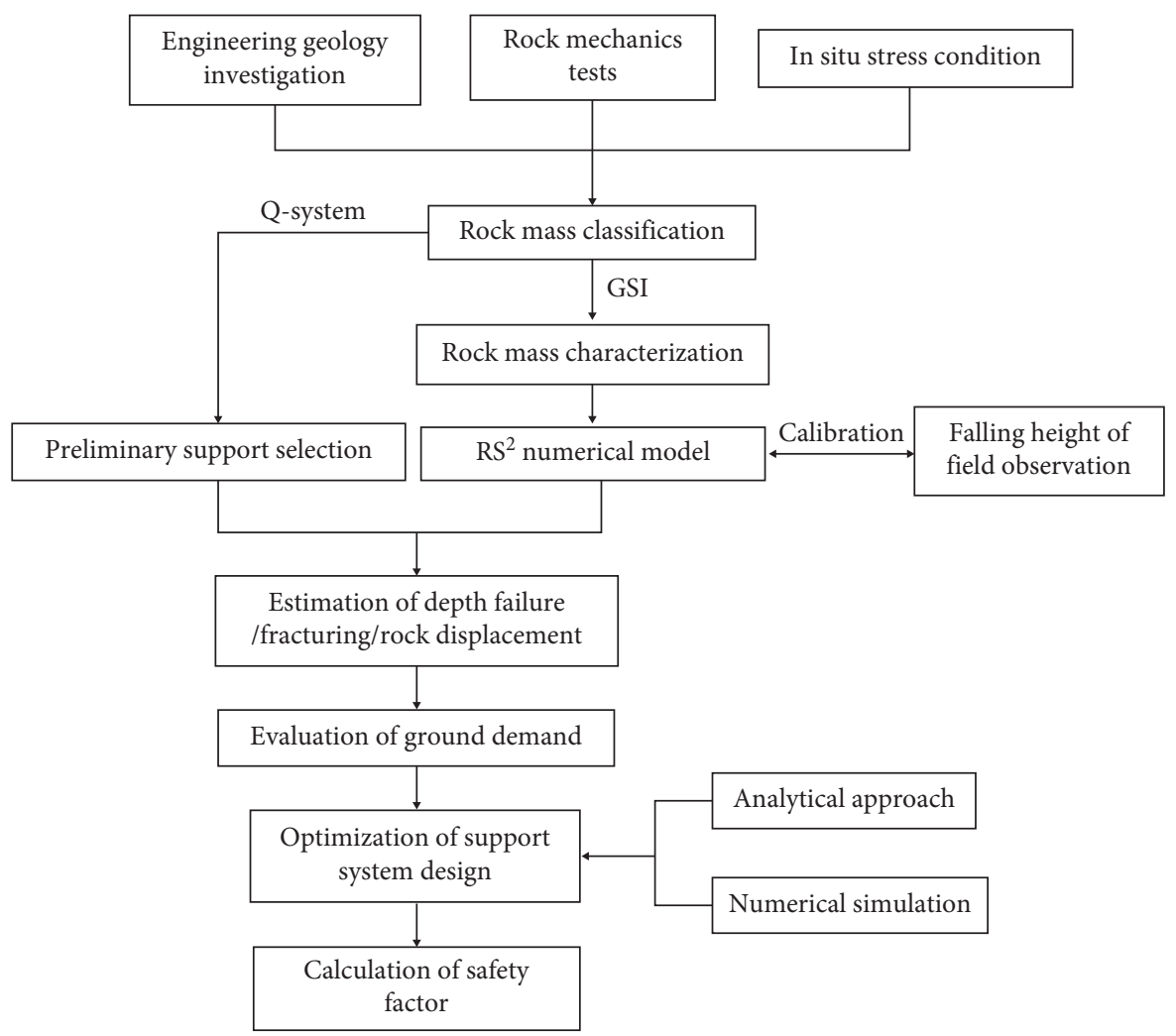

FIGURE 5: Flowchart of the systematic approach for support design of weak rock drift in Xinli mine. 


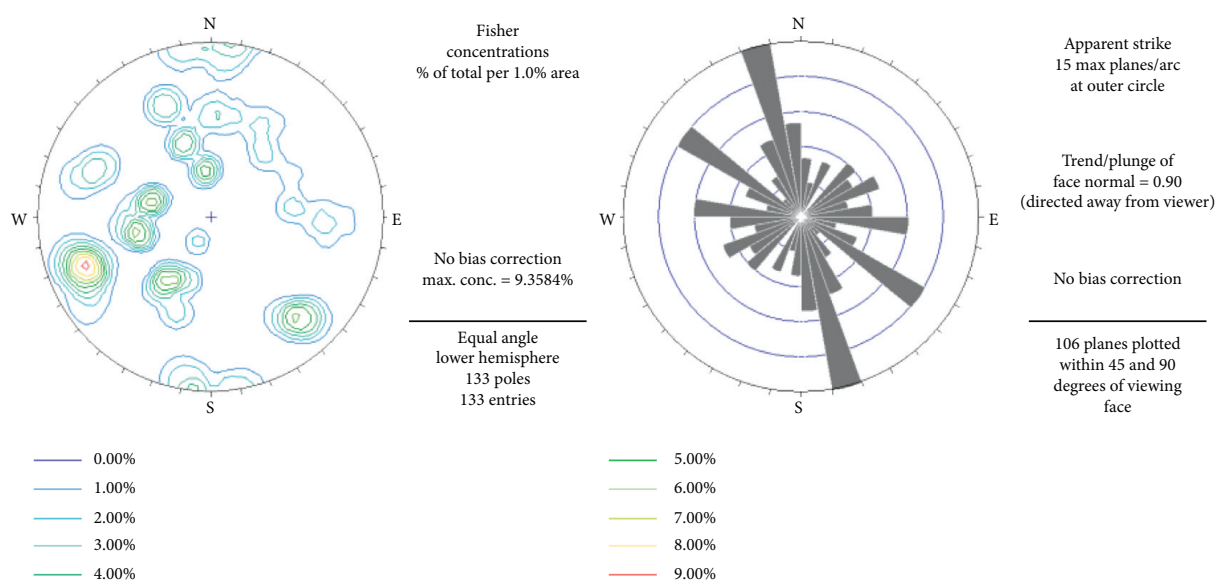

FIGURE 6: Dominant joint sets in the drifts between \#115 and \#159 exploration sections.

TABLE 1: Physical and mechanical properties of the phyllic granitic cataclasite in laboratory.

\begin{tabular}{lcc}
\hline Parameters & Unit & $-320 \mathrm{~m}$ \\
\hline Unit weight & $\mathrm{MN} / \mathrm{m}^{3}$ & 0.027 \\
Uniaxial compressive strength, $\sigma_{c}$ & $\mathrm{MPa}$ & 39.2 \\
Tensile strength, $\sigma_{t}$ & $\mathrm{MPa}$ & 5.3 \\
Deformation modulus, $E$ & $\mathrm{GPa}$ & 33.85 \\
Poisson's ratio, $v$ & & 0.24 \\
Cohesion, $c$ & $\mathrm{MPa}$ & 8.48 \\
Internal friction angle, $\varphi$ & $\circ$ & 40.4 \\
\hline
\end{tabular}

tested values are used in both the empirical and numerical methods implemented for this study.

4.3. In Situ Stress Field. In situ field test was carried out by using stress release technique. The direction and values of premining in situ stresses are shown in Table 2, which show a general increase linearly in stress with the depth varying.

4.4. Weak Rock Mass Classification. The qualification of the rock mass surrounding drift was assessed by using the Q-system [24] and GSI [25], which also are employed to assess the stability of rock masses for support design and also to determine the rock mass properties.

The Q-system was developed by Barton et al. [24] for design of support requirement for tunnel. The Q-system was updated on several occasions and it is now based on 1260 case records [26]. In the Q-system, RQD, the number of joint sets, the roughness of joint sets, the degree of alteration, ground water conditions, and Stress Reduction Factor (SRF) must be known to determine the quality of a rock mass. The SRF value can be set to 5.0, which is related to heavily jointed "sugar cube" in any depth [9], especially in weak rock mass.

The Geological Strength Index (GSI) developed by Hoek [27] is simple and fast, and it is based on the appearance of rock mass and its structure. The GSI values can be obtained from the quantitative GSI chart proposed by Marinos and Hoek [28]. The calculated $Q$ and GSI values of rock mass in the drift are shown in Table 3.
4.5. Estimation of Rock Mass Properties. The generalized Hoek-Brown failure criterion for rock masses uses $m_{\mathrm{b}}$, $s$, and a constants. Hoek et al.'s [29] suggested equations based on the empirical methods are used to calculate these constants. GSI value is related to parameters of Hoek-Brown strength criterion as follows [25, 27, 29]:

$$
\begin{aligned}
\sigma_{1}^{\prime} & =\sigma_{3}^{\prime}+\sigma_{c i}\left(m_{i} \frac{\sigma_{1}^{\prime}}{\sigma_{c i}}+s\right)^{a}, \\
m_{b} & =m_{i} \exp \left(\frac{\mathrm{GSI}-100}{28-14 \mathrm{D}}\right), \\
s & =\exp \left(\frac{\mathrm{GSI}-100}{9-3 \mathrm{D}}\right), \\
a & =\frac{1}{2}+\frac{1}{6}\left[\exp \left(-\frac{\mathrm{GSI}}{15}\right)-\exp \left(-\frac{20}{3}\right)\right],
\end{aligned}
$$

where $\sigma_{1}^{\prime}$ and $\sigma_{3}^{\prime}$ are maximum and minimum effective principal stresses at failure and $m_{\mathrm{i}}$ is the intact rock parameter. The constant $m_{\mathrm{i}}$ can be obtained by triaxial testing of rock. Additionally, the approximate values can also be estimated by a table presented by Marinos and Hoek [28]. In this study, the blasting quality was determined to be poor by field observations and thus the value of $D$ was considered to be 0.8 [29]. Equation (5) proposed by Hoek and Brown [25] based on Serafim and Pereira equation [30] was used to determine the deformation modulus $E_{\text {mass }}$ of rock masses (for $\sigma_{3}<100 \mathrm{MPa}$ ).

$$
E_{\text {mass }}=\sqrt{\frac{\sigma_{c i}}{100}} 10^{((\mathrm{GSI}-10) / 40)} .
$$

In addition, the tensile strength $\sigma_{\text {tmass }}$ of rock masses [28] is

$$
\sigma_{t \text { mass }}=\frac{-s \sigma_{c i}}{m_{b}}
$$

In rock engineering, many numerical model software packages use Mohr-Coulomb failure criterion. Therefore, it is necessary to determine equivalent friction angle and 
TABLE 2: In situ stress components at SW orebody of Xinli mine zone.

\begin{tabular}{lccc}
\hline Stress component & Magnitude $(\mathrm{MPa})$ & Trend & Value $(\mathrm{MPa})(\mathrm{depth}=320 \mathrm{~m})$ \\
\hline The major principal stress $\left(\sigma_{\mathrm{hmax}}\right)$ & $\sigma_{\mathrm{hmax}}=0.035 \mathrm{H}+0.11$ & $325^{\circ}$ & 11.31 \\
The minor principal stress $\left(\sigma_{\mathrm{hmin}}\right)$ & $\sigma_{\mathrm{hmin}}=0.018 \mathrm{H}+0.13$ & $145^{\circ}$ & 5.89 \\
The intermediate principal stress $\left(\sigma_{\mathrm{z}}\right)$ & $\sigma_{\mathrm{z}}=0.0315 \mathrm{H}+0.08$ & $0^{\circ}$ & 10.16 \\
\hline
\end{tabular}

$\mathrm{H}$ is the depth in meter.

cohesive strength of rock masses. The cohesive strength $c^{\prime}$ and friction angle $\varphi^{\prime}$ values can be calculated by the following two equations [29]:

$$
\begin{aligned}
& \varphi^{\prime}=\sin ^{-1}\left[\frac{6 a m_{b}\left(s+m_{b} \sigma_{3 n}\right)^{\alpha-1}}{2(1+a)(2+a)+6 a m_{b}\left(s+m_{b} \sigma_{3 n}\right)^{a-1}}\right] \\
& c^{\prime}=\frac{\sigma_{c i}\left[(1+2 a) s+(1-a) m_{b} \sigma_{3 n}\right]\left(s+m_{b} \sigma_{3 n}\right)^{\alpha-1}}{(1+a)(2+a) \sqrt{1+\left(6 a m_{b}\left(s+m_{b} \sigma_{3 n}\right)^{a-1}\right) /((1+a)(2+a))}}
\end{aligned}
$$

where $\sigma_{3 n}=\sigma_{3 \max } / \sigma_{c i} . \sigma_{3 \max }$ is the upper limit of confining stress over the relevant stress ranges between the HoekBrown and Mohr-Coulomb criteria. The relationship between $\sigma_{3 \max }$ and $\sigma_{\text {cmass }}$ is

$$
\frac{\sigma_{3 \max }}{\sigma_{\text {cmass }}\left(\sigma_{\text {cmass }} / \gamma H\right)^{-0.94}}
$$

where $\sigma_{\text {cmass }}$ is rock mass strength; $\gamma$ is the unit weight of the rock mass; and $\mathrm{H}$ is the depth of the excavation below surface. When the horizontal stress is higher than the vertical stress, the horizontal stress value should replace $\gamma \mathrm{H}$.

The mechanics parameters of rock mass along the drift were summarized and listed in Table 4.

\section{Numerical Model}

5.1. Numerical Model. The two-dimensional FEM plane strain model is conducted based on the dimensions of this straight-sided arch drift using RS2 program developed by Rocscience [20]. A standard 2D model is $30 \mathrm{~m} \times 30 \mathrm{~m}$ in dimensions, and an automatically generated finite element mesh around the straight-sided arch section of drift with $3.6 \mathrm{~m}$ width and $3.3 \mathrm{~m}$ height was shown in Figure 7 . The rock mass is assumed as "ideally" elastic-plastic material and the rock mass properties used in this analysis were obtained from the estimated parameters given in Section 4. The generalized Mohr-Coulomb strength criterion was used to identify elements undergoing yielding and plastic behavior in rock masses [31]. In this simulation, the major horizontal stress was assumed to be parallel to the drift axis. Thus, the vertical and minor horizontal stresses are in the excavation plane and the major horizontal principal stress is out of the plane. The bottom, left, and right sides of the model are fixed. The numerical analysis includes the full- face excavation and support on the excavation boundary. The first stage allows the model to give the stress and displacement under gravitational loading system without any excavation. The subsequent displacements and stress situation were determined in the second stage by excavation and support.

5.2. Calibration against Field Observation. A wide range of falling areas have been observed after drill and blast, and the falling height and failure shapes of weak rock drift were shown in Figure 3. Coates [32], Bucky [33], and Kendorski [34] discuss field experience with induced falling from block size, rock strength, in situ stress, span of drift, and rock fracturing. According to the result of field observation and rock mass classification, the $Q$ index value of drift is 0.23 (very poor). $\mathrm{RQD} / \mathrm{Jn}=35 / 15=2.3=$ smaller blocks, which is heavily jointed "sugar cube," relative frictional strength $=\mathrm{Jr} /$ $\mathrm{Ja}=0.5$, and function $\varnothing=\arctan (\mathrm{Jr} / \mathrm{Ja})=26.6^{\circ}$ [24]. The joint plane is smooth and planar, where there is a potential domeshaped falling zone in the roof.

In order to observe the fall propagation process, the numerical procedure was used to investigate the domeshaped falling zone with the Mohr failure envelope with various friction angles of $26.6^{\circ}, 34.6^{\circ}$, and $40.4^{\circ}$ obtained from the empirical method, calculated rock mass parameters, and rock mechanics test, respectively.

Model result presented the shape and height of falling in the weak rock drift, shown in Figure 8. In this figure, the falling heights were governed by the frictional properties when the drift span, rock block size, in situ stress, and rock mass strength are constant. From the shape and height of falling in weak rock drift (Figure 8), it can be inferred that the drift falling is caused by frictional properties of weak rock. When the value of frictional angle is $\varnothing=34.6^{\circ}$, the 
TABLE 3: Rock mass classification results by using Q-system and GSI-system in the drift.

\begin{tabular}{lcccccccc}
\hline \multirow{2}{*}{ Level } & \multicolumn{4}{c}{ Rating } & \multicolumn{3}{c}{ G } & \multicolumn{2}{c}{ GSI } \\
& RQD & Jn & Jr & Ja & Jw & SRF & & Q \\
\hline$-320 \mathrm{~m}$ & 35 & 15 & 2.0 & 4.0 & 1 & 5 & 0.23 & 41 \\
\hline
\end{tabular}

TABle 4: The mechanics parameters of weak rock drift.

\begin{tabular}{lcccccc}
\hline \multirow{2}{*}{ Level } & Deformation modulus & Tensile strength & Compressive strength & Friction angle & Cohesive strength & Poisson's ratio \\
& $E_{\text {mass }}$ & $\sigma_{\text {tmass }}$ & $\sigma_{\text {cmass }}$ & $\varphi^{\prime}$ & $c^{\prime}$ & ${ }^{\prime}$ \\
\hline Units & $\mathrm{GPa}$ & $\mathrm{MPa}$ & $\mathrm{MPa}$ & 34.6 & $\mathrm{MPa}$ & 0.80 \\
$-320 \mathrm{~m}$ & 7.29 & 0.0065 & 3.95 & 34.6 & 0.24 \\
\hline
\end{tabular}

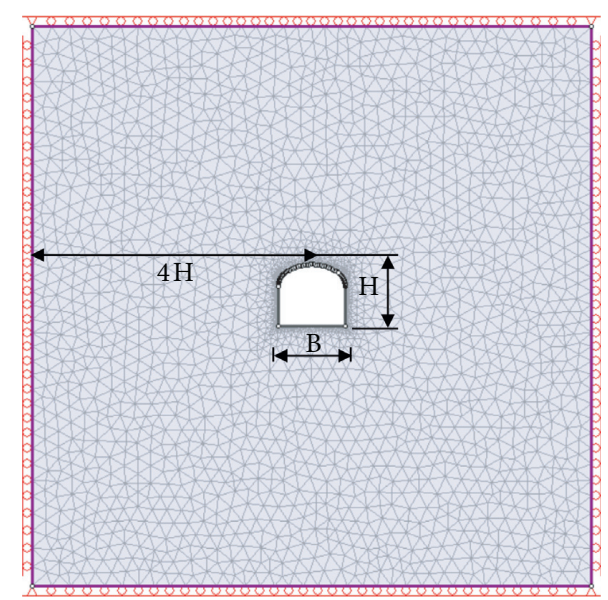

Figure 7: The model's meshes, geometry, and boundary conditions.

shape and height of falling are in accordance with the result obtained from the field observation in Figures 3 and 4.

In order to further verify frictional properties, the Mohr circles are tangent to a Mohr envelope given by the normal and shear stress that exists on the material failure surface at failure obtained by solving the following equations:

$$
\begin{aligned}
\tau & =(\cot \varnothing-\cos \varnothing) \frac{m \sigma_{c}}{8}, \\
\varnothing & =\arctan \frac{1}{\sqrt{4 h \cos ^{2} \theta-1}}, \\
\theta & =\frac{1}{3}\left(90+\arctan \frac{1}{\sqrt{h^{3}-1}}\right) .
\end{aligned}
$$

The frictional properties of weak rock were examined by numerical simulation and analytical solution, and the fitting friction angle is $34.6^{\circ}$, which is the most significant one with respect to drift falling in weak rock. It can be found that the numerical simulation can further analyze the support design in weak rock.

5.3. Numerical Model for Analyzing the Support. When the drift is driven in the weak rock, the potential falling problem can be encountered. To stabilize these drifts falling, the most sophisticated steel sets support technique similar to that which has been used early was implemented, the steel sets (spacing $1.5 \mathrm{~m}$ ) and shotcrete (thickness $150 \mathrm{~mm}$ ) were immediately installed for preventing heavily jointed rock falling. But the ground problems tend to become severe (Figure 3), because the support with steel sets and shotcrete cannot enhance the stiffness of weak rock and only prevents surface falling of the roof, which cannot availably control the drift stability in weak rock.

Subsequently, the geotechnical investigations were required and involved in the field observation of roof falling, rock mass failure, support performance, and in situ stress condition. Based on the geotechnical analysis shown in Section 4.4, the calculated Q value is combined with the dimension of drift in a support chart. The primary support design suggested by Q-system is a combination of $2.0 \mathrm{~m}$ long resin rebar with $1.3 \mathrm{~m}$ spacing and $90 \mathrm{~mm}$ thickness reinforced fiber shotcrete, the support system was installed instantly after blast. But the low Q value also provides a key geotechnical parameter of determining the maximum span exceeding the acceptable probability of failure. The support design suggested by Q-system cannot also provide enough support capacity to control the instability of weak rock drift.

For further definition of the support requirements and reinforcement surrounding the weak rock drift, the convergence-confinement method developed by Fenner [35] in 1960s and 1970s was utilized to estimate the support demand. The basic procedure of convergence-confinement method is the load imposed on a support installed behind the roof surface of drift to be estimated. Based upon analyses of case records, Grimstad and Barton [26] suggest that the relationship between the $\mathrm{Q}$ value and the permanent roof support pressure proof is estimated from the following equation:

$$
\mathrm{P}_{\text {roof }} \leq \frac{2 \cdot J_{n}^{(1 / 2)} \cdot(\mathrm{Q})^{-(1 / 3)}}{3 \mathrm{~J}_{\mathrm{r}}}
$$

The weak rock mass, in which the drift is excavated, is assumed to satisfy Hoek-Brown failure criterion. The critical support pressure, $p_{i}^{c r}$, is defined as

$$
p_{i}^{c r}=\left[P_{0}^{c r}-\frac{s}{m_{b}^{2}}\right] m_{b} \times \sigma_{c i},
$$

where $p_{i}^{c r}$ is the critical support pressure, $\sigma_{c i}$ is the unconfined compressive strength of intact rock, $m_{b}$ and $s$ are 


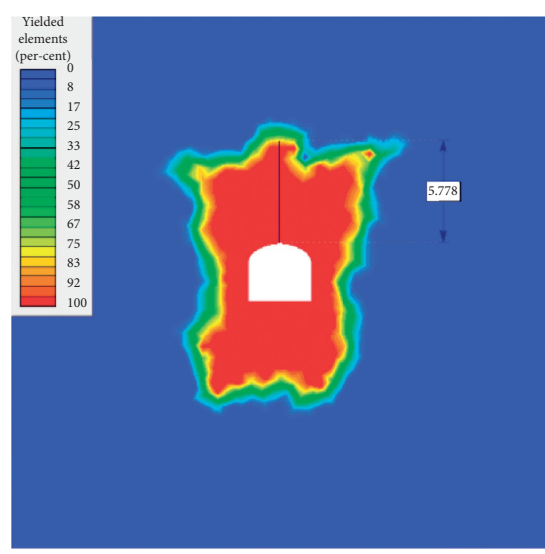

(a)

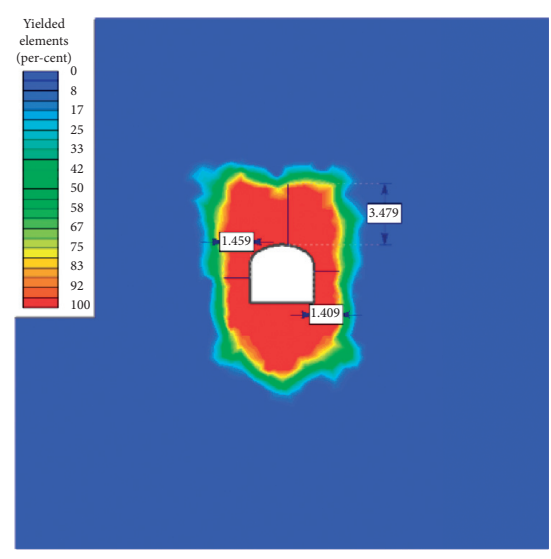

(b)

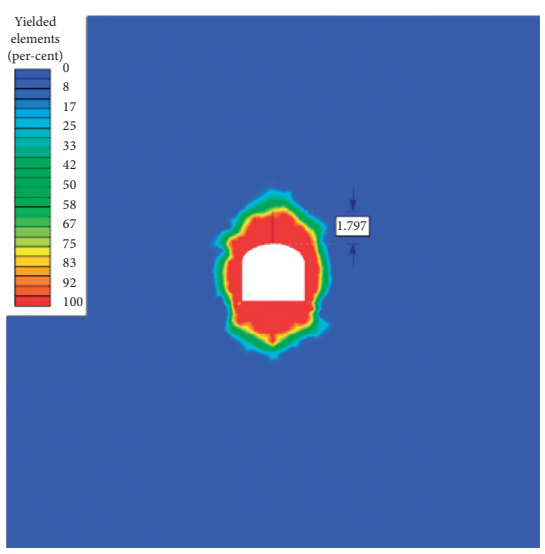

(c)

Figure 8: The shape and height of predicted yielding zone in weak rock drift according to various friction angles. (a) $\varnothing=26.6^{\circ}$. (b) $\varnothing=34.6^{\circ}$. (c) $\varnothing=40.4$.

the rock mass parameters, and $P_{0}^{c r}$ is the scaled critical (internal) pressure given by the following expression:

$$
P_{0}^{c r}=\frac{1}{16}\left[1-\sqrt{1+16 S_{0}}\right]^{2} .
$$

In equation (15), $S_{0}$ is the scaled far-field stress calculated by the following equation:

$$
S_{0}=\frac{\sigma_{0}}{m_{b} \times \sigma_{c i}}+\frac{s}{m_{b}^{2}}
$$

If the internal support pressure $p_{\mathrm{i}}$ is greater than this critical pressure $p_{i}^{c r}$, no failure will occur. In this case, the behavior of surrounding rock mass is radial elastic displacement of drift wall $u_{r}^{e l}$ given by the following equation:

$$
u_{r}^{e l}=\frac{\sigma_{0}-P_{i}}{2 G_{r m}},
$$

where $G_{r m}$ is the shear modulus of rock mass.

If the internal support pressure $i$ is less than critical support $p_{i}^{c r}$, failure occurs. Then the radius of broken zone, $R_{p l}$, is defined by the following equation:

$$
R_{p l}=R \cdot \exp \left[2\left(\sqrt{P_{i}^{c r}}-\sqrt{P_{i}}\right)\right]
$$

For weak rock, the results of critical support pressure, radius of plastic zone, and maximum deformation are calculated by analytic method. The support capacity of rock bolt is assumed to the capacity of each bolt divided by the area it has to support.

The bolt length $L_{b}$ can be estimated in terms of excavation width $\mathrm{B}$ or height $\mathrm{H}$ for roof and wall by the following equation proposed by Barton et al. [24]:

$$
L_{b}=2+(0.15 B \text { or H/ESR }) \text {. }
$$

The support design has been presented in Table 5, and the input weak rock mass parameters in Table 4 required for numerical analysis have been utilized in the analyses. The properties of the support elements are presented in Table 6, including steel set, shotcrete, rock bolt, and cable bolt. The numerical models used for all three kinds of support designs were shown in Figure 9.

The combination support system (Table 5) consists of a $100 \mathrm{~mm}$ thickness shotcrete; $1 \mathrm{~m} \times 1 \mathrm{~m}$ pattern of $2.5 \mathrm{~m}$ long, $20 \mathrm{~mm}$ diameter, fully resin grouted rebar, wire mesh, and steel straps; $150 \mathrm{~mm}$ thickness shotcrete; and $1.5 \mathrm{~m} \times 1.5 \mathrm{~m}$ pattern of $4.5 \mathrm{~m}$ long cable bolt and steel straps (in sequence).

\section{Numerical Modeling Result Analysis}

In order to overcome the limitations of analytical solution and evaluate the performance of 3 different support designs, a tool for practical support design calculations, called RS2D and described in Section 5.1, was employed to model and analyze the 3 different support designs. The depth of the plastic zone and displacement contours surrounding the drift can be clearly demonstrated using comparative numerical models, shown in Figures 10-12 and Table 7. As the results of the all analyses were examined, the depth of plastic zone and displacement surrounding the drift decreased in different extent; in particular, depth of plastic zone and displacement in the roof and FOS relatively increased.

The sophisticated support recommends the utilization of steel sets and shotcrete as support elements, that is, outer surface support devices. The sophisticated support has much more stability problems surrounding the drift (Figures 10(a), 11(a), and 12) in contrast to the other two support designs. The support resistance was provided by the surface support element, which cannot change the mechanical properties of weak rock. The depth of the plastic zone has the values of $2.557 \mathrm{~m}, 0.944 \mathrm{~m}$, and $0.933 \mathrm{~m}$ in roof, left wall, and right wall, respectively (Table 7). The numerical results demonstrate the reliability of falling height estimation compared with field observation (Figure 3 ). The larger areas of dome plastic zone lead to the deformation of steel sets, which cannot effectively maintain the drift stability.

It can be seen that, after support installation suggested by Q-system (Table 7 and Figure 10(b)), not only the number of 
TABle 5: Detailed design parameters of different support systems.

\begin{tabular}{|c|c|c|c|}
\hline & $\begin{array}{l}\text { Sophisticated support } \\
\text { (Figure 9(a)) }\end{array}$ & Support suggested by Q-system (Figure 9(b)) & Combination support system (Figure 9(c)) \\
\hline Steel set & $100 \mathrm{~mm}$ wide & - & - \\
\hline Shotcrete & $150 \mathrm{~mm}$ thickness & $90 \mathrm{~mm}$ thickness reinforced fiber shotcrete & $100 \mathrm{~mm}$ thickness, $150 \mathrm{~mm}$ thickness \\
\hline Rock bolt & - & $\begin{array}{c}1.3 \mathrm{~m} \times 1.3 \mathrm{~m} \text { pattern of } 2 \mathrm{~m} \text { long, } 20 \mathrm{~mm} \\
\text { diameter, fully resin grouted rebar }\end{array}$ & $\begin{array}{c}1 \mathrm{~m} \times 1 \mathrm{~m} \text { pattern of } 2.5 \mathrm{~m} \text { long, } 20 \mathrm{~mm} \\
\text { diameter, fully resin grouted rebar }\end{array}$ \\
\hline Cable bolt & - & - & $\begin{array}{c}1.5 \mathrm{~m} \times 1.5 \mathrm{~m} \text { pattern of } 4.5 \mathrm{~m} \text { long, fully cement } \\
\text { grouted }\end{array}$ \\
\hline $\begin{array}{l}\text { Wire } \\
\text { mesh }\end{array}$ & - & \#0 gauge mesh & $\# 0$ gauge mesh \\
\hline Steel strap & - & - & \#4 screen \\
\hline
\end{tabular}

Gauge mesh is a standard specification wire mesh.

TABle 6: The properties of the support elements employed in the analyses.

\begin{tabular}{lccccccc}
\hline $\begin{array}{l}\text { Material } \\
\text { type }\end{array}$ & $\begin{array}{c}\text { Unit weight } \\
\left(\mathrm{MN} / \mathrm{m}^{3}\right)\end{array}$ & $\begin{array}{c}\text { Young's } \\
\text { modulus }(\mathrm{GPa})\end{array}$ & $\begin{array}{c}\text { Poisson's } \\
\text { ratio }(v)\end{array}$ & $\begin{array}{c}\text { Cohesion, c } \\
(\mathrm{MPa})\end{array}$ & $\begin{array}{c}\text { Internal friction } \\
\text { angle } \phi\left(^{\circ}\right)\end{array}$ & $\begin{array}{c}\text { Compressive } \\
\text { strength }(\mathrm{MPa})\end{array}$ & $\begin{array}{c}\text { Tensile } \\
\text { strength }(\mathrm{MPa})\end{array}$ \\
\hline Shotcrete & 0.024 & 24 & 0.20 & 2 & 37 & 30 & 3.5 \\
Rock bolt & 0.079 & 200 & - & - & - & - & 365 \\
Wire mesh & - & 200 & 0.35 & - & 25 & - & 365 \\
Cable bolt & 0.078 & 202 & - & 2 & - & 1860 \\
\hline
\end{tabular}

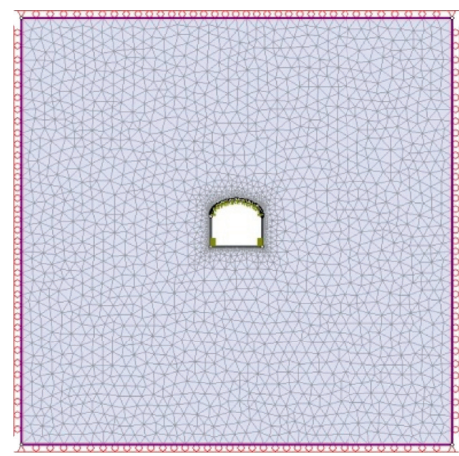

(a)

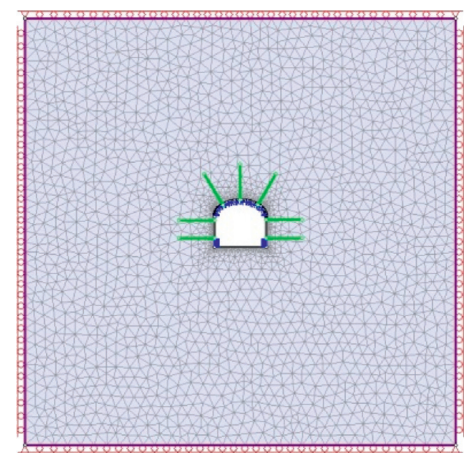

(b)

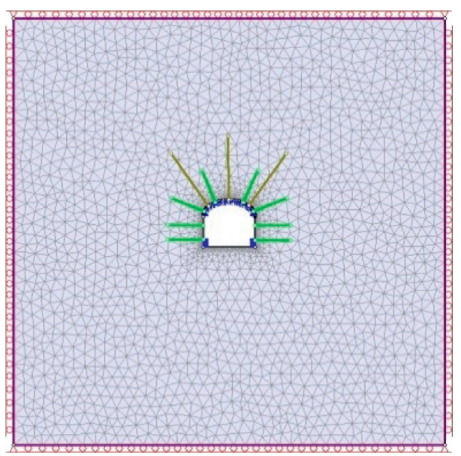

(c)

FIgURE 9: Numerical models using RS2 program for (a) sophisticated support, (b) support suggested by Q-system, and (c) the combination support system.

yielded elements but also the extent of the plastic zone decreased substantially; that is, the depth of the plastic zone and displacement surrounding the drift descended. Figure 10(b) shows the estimation depth of plastic zone surrounding the drift after installation of rock bolt with mesh and shotcrete suggested by the Q-system, which is about $1.634 \mathrm{~m}, 0.869 \mathrm{~m}$, and $0.88 \mathrm{~m}$ in roof, left wall, and right wall, respectively (Table 7 ). The depth of plastic zone is less than those of sophisticated support because of installing rock bolt to reinforce fractured rock and increasing the frictional forces of smooth rock block by forcing rock blocks together. But recommended $2 \mathrm{~m}$ bolt length, much less than the $3.479 \mathrm{~m}$ depth of plastic zone in unsupported drift, and the rock bolt change partially the mechanical properties of weak rock. The horizontal displacement surrounding drift is estimated as $11.2 \mathrm{~mm}$ close to those of sophisticated support after installing rock bolt (Figure 12), and the displacement in roof is less than that of sophisticated support (Figure 11). The support suggested by the Q-system approach is suitable for light or medium jointed rock mass zones that have local support close to the internal surface but have not been cablebolted.

Figures $10(\mathrm{c})$ and $11(\mathrm{c})$ show the estimation depth of plastic zone surrounding the drift that has the combination support system installed, which is about $0.336 \mathrm{~m}$, $0.528 \mathrm{~m}$, and $0.683 \mathrm{~m}$ in roof, left wall, and right wall, respectively. Apparently, the combination supports strengthen fractured rock and resistance to deformation of the fractured rock mass, and the $4.5 \mathrm{~m}$ length of cable bolt is larger than the depth of plastic zone in unsupported condition. The combination of rock bolt and cable bolt completely changes the mechanical properties of weak rock, which especially provides enough frictional and interlocked forces to resist weak rock falling and further provides an effective holding function by the shotcrete, mesh, and steel strap in weak rock. The total displacement values decreased to $2 \mathrm{~mm}$ in roof. But, due to the lack of reinforced support in side walls of drift, the displacements 


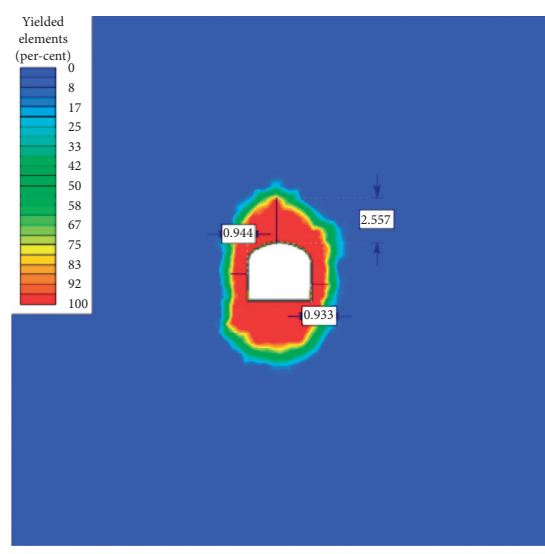

(a)

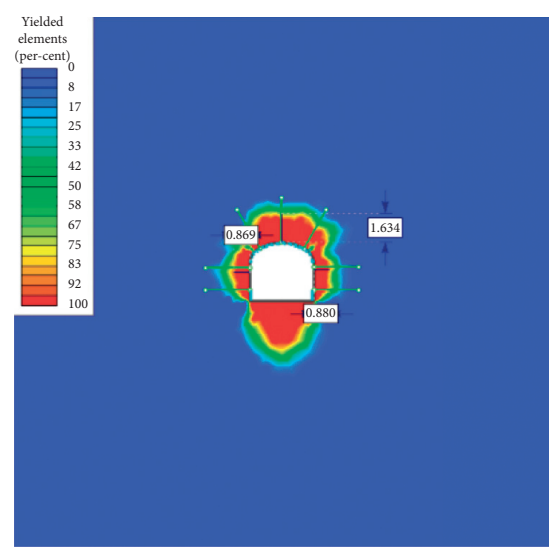

(b)

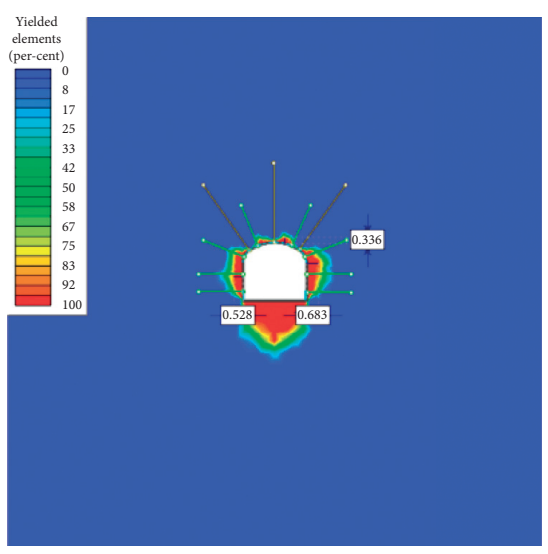

(c)

Figure 10: Depth of plastic zone surrounding the drift for (a) sophisticated support, (b) support suggested by Q-system, and (c) the combination support system.

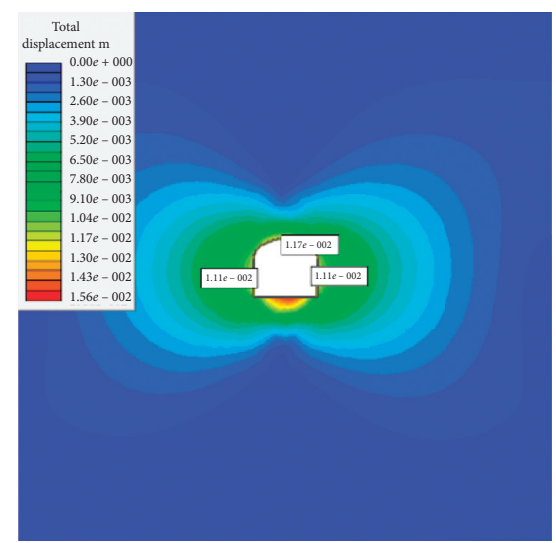

(a)

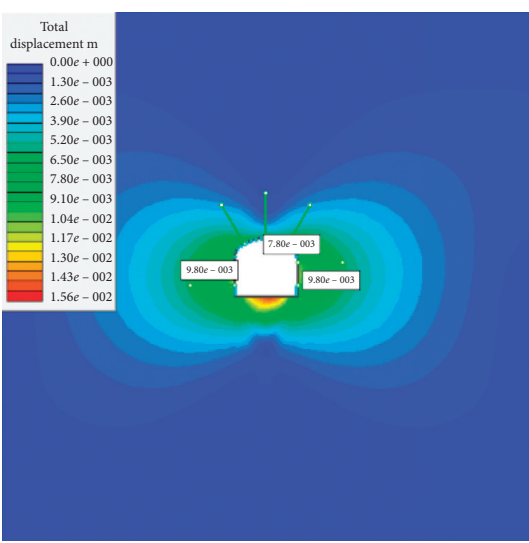

(b)

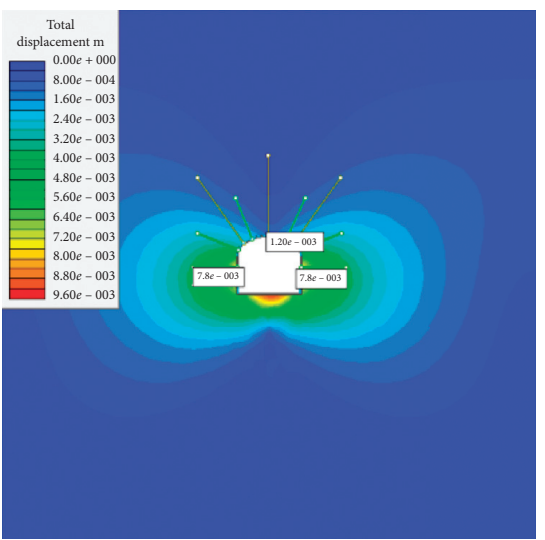

(c)

FIgURE 11: The total displacement surrounding the drift for (a) sophisticated support, (b) support suggested by Q-system, and (c) the combination support system.

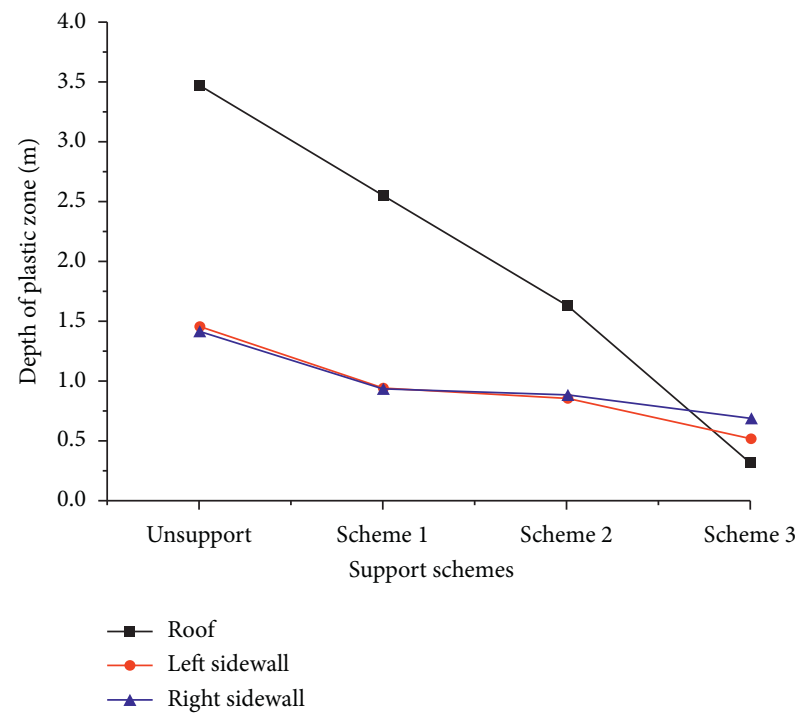

(a)

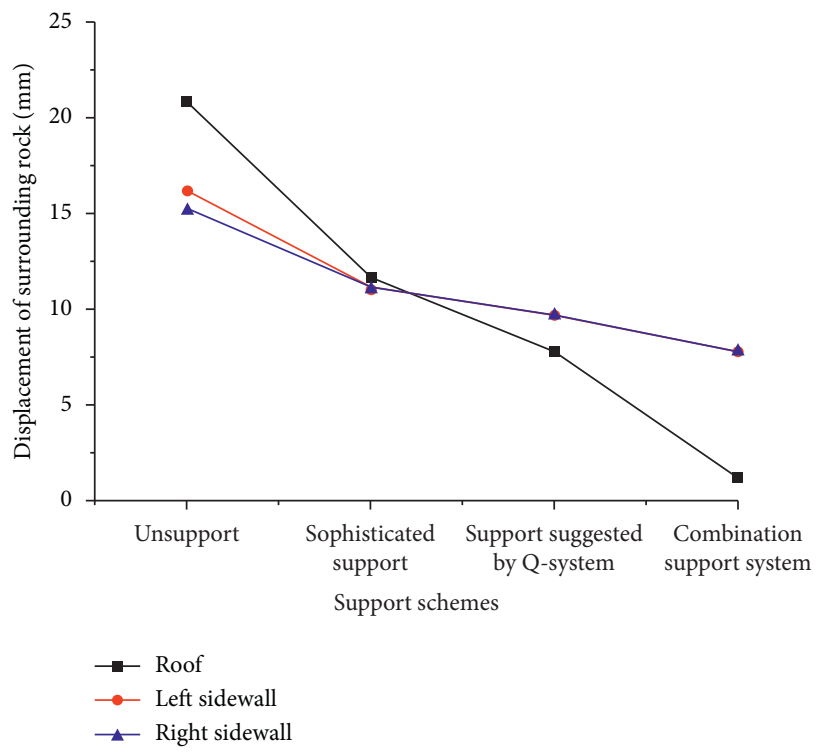

(b)

Figure 12: The depth of plastic zone and total displacement surrounding the drift for 3 different support designs. 
TABle 7: Depth of plastic zone, displacement, and FOS of different support design obtained from RS2.

\begin{tabular}{|c|c|c|c|c|c|}
\hline & & Unsupported & $\begin{array}{l}\text { Sophisticated } \\
\text { support }\end{array}$ & $\begin{array}{l}\text { Support suggested by Q- } \\
\text { system }\end{array}$ & $\begin{array}{c}\text { Combination } \\
\text { support system }\end{array}$ \\
\hline \multirow{3}{*}{ The depth of plastic zone/m } & \multirow{3}{*}{$\begin{array}{l}\text { Roof } \\
\text { Left side wall } \\
\text { Right side } \\
\text { wall }\end{array}$} & 3.479 & 2.557 & 1.634 & 0.336 \\
\hline & & 1.459 & 0.944 & 0.869 & 0.528 \\
\hline & & 1.409 & 0.933 & 0.88 & 0.683 \\
\hline $\begin{array}{l}\text { Vertical displacement in the roof/ } \\
\mathrm{mm}\end{array}$ & & 22 & 12 & 7.6 & 2 \\
\hline \multirow[b]{2}{*}{ Horizontal displacement/mm } & Left side wall & 19.5 & 13.4 & 11.2 & 9.55 \\
\hline & $\begin{array}{l}\text { Right side } \\
\text { wall }\end{array}$ & 16.5 & 13.4 & 11.2 & 8.45 \\
\hline Factor of safety (FOS) & & 0 & 0.17 & 0.88 & 8.28 \\
\hline
\end{tabular}

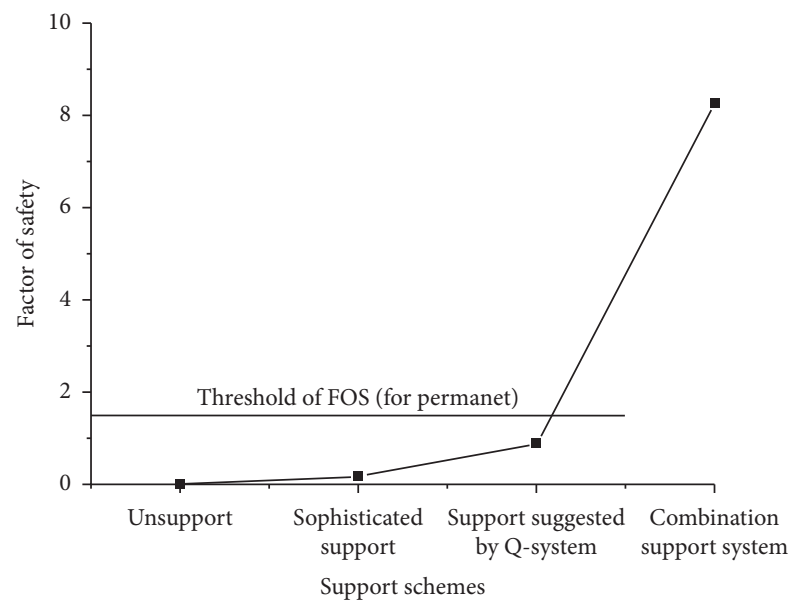

FIGURE 13: FOS surrounding the weak rock drift obtained from 3 different support designs.

of side walls are $9.55 \mathrm{~mm}$ and $8.45 \mathrm{~mm}$, respectively, which are much more than $2 \mathrm{~mm}$ in roof (Figure 12), which needs to adjust the support parameters in side walls of weak rock drift.

A factor of safety of more than one may provide stability under loading conditions. The FOS of drift is defined as the ratio of loading capacity of ground support system to total effective load on the ground surrounding drift. The failure is assumed to occur when FOS is less than 1.5 for permanent drift (Figure 13).

Consider the case of support patterns obtained from sophisticated support, support suggested by Q-system, and the combination support system which are designed to hold up the rock falling in the roof of drift. Figure 10 shows the depth of plastic zone failure being supported by different support patterns. The unit weight of weak rock is $2.72 \mathrm{t} / \mathrm{m}^{3}$. The mean falling height can be obtained from field observation, and the falling weight being carried by the different support patterns. The demand on capacity of the different support patterns is larger than the weight of falling rock mass. A factor of 1.5 to 2.0 is generally considered adequate for a "permanent" excavation. The calculated FOS results and the comparative curves of different support patterns are shown in Table 7 and
Figure 13. The proposed FOS of the combination support system is 8.28 , which can be further adapted to provide guidance for holding on the rock falling in the weak rock drift.

\section{Conclusions and Suggestions}

In this study, a systematic approach for support design of weak rock drift has been developed to estimate weak rock support demand and design support system. A combination support design is proposed based on the systematic analytical approach by increasing the frictional properties and interlocked forces of smooth weak rock, strengthening the interaction between the combination support and the rock surface, and enhancing the effective holding function of surface support in restricting roof falling.

The RS2 numerical simulation was used to compare the sophisticated support, support suggested by Q-system, and the combination support system. The numerical results demonstrate that sophisticated support only holds outer surface support and support suggested by Q-system using internal rock bolt support partially strengthens the weak rock properties. The combination support system increases the frictional forces of rock blocks, resistance to deformation of the fractured rock mass, and the support of the dead weight surrounding a weak rock drift. The depth of plastic zone and total deformation using the combination support system in the weak rock drift significantly descended $87 \%$ and $90 \%$ of those of sophisticated support. The FOS value of 8.28 in combination support system can be sufficient to stabilize the weak rock drift, which has also been successfully implemented in weak rock drift and was more effective.

\section{Data Availability}

The data used to support the findings of this study are included within the article.

\section{Conflicts of Interest}

The authors declare that there are no conflicts of interest. 


\section{Acknowledgments}

This work was supported by the Project of NSFC-Shandong Joint Fund (U1806208), National Key Research \& Development Project (2016YFC0600803 and 2018YFC0604604), the Fundamental Research Funds for the Central Universities (N2001033), and the Opening Project of State Key Laboratory of Nickel and Cobalt Resources Comprehensive Utilization.

\section{References}

[1] T. Durmeková, J. Frankovská, and M. Kopecký, “Correlation between point load index and uniaxial compressive strength for soft and weak rocks," Acta Geológica Slovaca, vol. 6, no. 1, pp. 61-69, 2014.

[2] Q. Záruba and V. Mencl, Engineering Geology (in Czech), Academia, Praha, Slovakia, 1974.

[3] K. Skrzypkowski, "The influence of room and pillar method geometry on the deposit utilization rate and rock bolt load," Energies, vol. 12, no. 24, p. 4770, 2019.

[4] E. Hoek, "Tunnel support in weak rock. keynote address," in Proceedings of the Symposium of Sedimentary Rock Engineering, pp. 20-22, Taipei, Taiwan, November 1998.

[5] S. A. Klein, "Measuring, estimating, and understanding the psychometric function: a commentary," Perception \& Psychophysics, vol. 63, no. 8, pp. 1421-1455, 2001.

[6] J. I. Mathis and C. H. Page, "Drifting in very poor rock-experience and analysis," in Presented at the 101st Annual Northwest mining conventionSpokane, Washington, D.C, USA, 1995.

[7] T. Brady, L. Martin, and R. Pakalnis, "Empirical approaches for opening design in weak rock masses," Mining Technology, vol. 114, no. 1, pp. 13-20, 2005.

[8] A. Palmström, "Combining the RMR, Q, and RMi classification systems," Tunnelling and Underground Space Technology, vol. 24, no. 4, p. 491, 2009.

[9] A. Palmström and E. Broch, "Use and misuse of rock mass classification systems with particular reference to the Q-system," Tunnelling and Underground Space Technology, vol. 21, no. 6, pp. 575-593, 2006.

[10] B. Foo, A. A. Lima, and B. Vries, "Practical application of ground support and reinforcement to address weak rock mass in underground mines," VII South American Congress on Rock Mechanics, vol. 16, p. 30, 2010.

[11] P. A. Mikula and M. F. Lee, "Confirmation of Q classification for use at Mt. Charlotte mine," in Proceedings of the First Australasian Ground Control in Mining Conference, pp. 179-183, Sydney, Australia, November 2003.

[12] E. Hoek, P. K. Kaiser, and W. F. Bawden, Support of underground excavations in hard rock, August Aimé Balkema, Rotterdam, The Netherlands, 1995.

[13] E. Hoek and M. S. Diederichs, "Empirical estimation of rock mass modulus," International Journal of Rock Mechanics and Mining Sciences, vol. 43, no. 2, pp. 203-215, 2006.

[14] W. X. Wu, F. Q. Gong, and W. M. Yang, "Experimental simulation study of spalling in deep rectangular tunnel with plastic fine grain marble," Tunnelling and Underground Space Technology, vol. 98, 2020.

[15] Y. Luo, F.-Q. Gong, X.-B. Li, and S.-Y. Wang, "Experimental simulation investigation of influence of depth on spalling characteristics in circular hard rock tunnel," Journal of Central South University, vol. 27, no. 3, pp. 891-910, 2020.
[16] Z. A. Song and Y. Chang, "Key technology of full-mechanized caving mining under sea in longkou," Coal Mining Technology, vol. 14, no. 1, pp. 48-51, 2009, in Chinese.

[17] X. Li, D. Li, Z. Liu, G. Zhao, and W. Wang, "Determination of the minimum thickness of crown pillar for safe exploitation of a subsea gold mine based on numerical modelling," International Journal of Rock Mechanics and Mining Sciences, vol. 57, pp. 42-56, 2013.

[18] Z. X. Liu, W. G. Dang, and X. Q. He, "Undersea safety mining of the large gold deposit in xinli district of sanshandao gold mine," International Journal of Minerals, Metallurgy and Materials, vol. 19, no. 7, pp. 574-583, 2012.

[19] International Society for Rock Mechanics (ISRM), "Commission on standardization of laboratory and field tests: suggested methods for the quantitative description of discontinuities in rock masses," International Journal of Rock Mechanics and Mining Sciences \& Geomechanics Abstract, vol. 15, no. 6, pp. 319-368, 1981.

[20] Rocscience, P.2 v8.0 Finite Element Analysis for Excavations and Slopes, Rocscience Inc., Toronto, Canada, 2011.

[21] Z. T. Bieniawski, Engineering Rock Mass Classifications, Wiley, New York, NY, USA, 1989.

[22] A. Palmström, "The volumetric joint count-a useful and simple measure of the degree of jointing," in Proceedings IV International Congress IAEG, pp. 221-228, New Delhi, India, September 1982.

[23] D. J. Hutchinson and M. S. Diederichs, Cablebolting in Underground Mines, Bitech Publishers Ltd., Toronto, Canada, 1996.

[24] N. Barton, R. Lien, and J. Lunde, "Engineering classification of rock masses for the design of tunnel support," Rock Mechanics, vol. 6, no. 4, pp. 189-236, 1974.

[25] E. Hoek and E. T. Brown, "Practical estimates or rock mass strength," International Journal of Rock Mechanics and Mining Sciences and Geomechanics Abstract, vol. 34, no. 8, pp. 1165-1186, 1997.

[26] E. Grimstad and N. Barton, "Updating of the Q-system for NMT," in Proceedings of the International Symposium on Sprayed Concrete. Shapern Use of Wet Mix Sprayed Concrete for Underground SupportNorwegian Concrete Association, Oslo, Norway, 1993.

[27] E. Hoek, "Strength of rock and rock masses," ISRM News Journal, vol. 2, no. 2, pp. 4-16, 1994.

[28] P. Marinos and E. Hoek, "A geologically friendly tool for rock mass strength estimation," in Proceedings of the ISRM International Symposium. International Society for Rock Mechanics and Rock Engineering, pp. 1422-1442, Melbourne, Australia, November 2000.

[29] E. Hoek, C. Carranza-Torres, and B. Corkum, "Hoek-brown failure criterion-2002 edition," in Proceedings of the NARMSTAC 2002, Mining Innovation and Technology. Toronto-10 July 2002, University of Toronto, Torointo, China, pp. 267273, July 2002.

[30] J. L. Serafim and J. P. Pereira, "Considerations on the geomechanical classification of bieniawski," in Proceedings of the International Symposium on Engineering Geol and Underground Construction, pp. 33-44, Lisbon, Portugal, November 1983.

[31] J. Liu, X.-D. Zhao, S.-J. Zhang, and L.-K. Xie, "Analysis of support requirements for underground water-sealed oil storage cavern in China," Tunnelling and Underground Space Technology, vol. 71, no. 1, pp. 36-46, 2018. 
[32] D. F. Coates, Priciples of Rock Mechanics, Monograph 874; CANMET, Energy, Mines and Resources, Toronto, Canada, 1981.

[33] P. B. Bucky, "Fundamental considerations in block caving the 1st US symposium on rock mechanics (USRMS)," American Rock Mechanics Association, vol. 51, no. 3, pp. 129-146, 1956.

[34] F. S. Kedorski, "The cavability of ore deposits," Mining Engineering, vol. 30, no. 6, pp. 628-631, 1978.

[35] R. Fenner, "Untersuchungen zur erkenntnis des gebirgsdruckes," Glückauf, vol. 32, pp. 681-695, 1938. 